\title{
Model Geoprocessing Untuk Otomatisasi Pemetaan Daerah Rawan Banjir Berbasis Geographic Information System
}

\author{
Nizar Purnama ${ }^{1}$, Nasaruddin ${ }^{2}$, Nizamuddin ${ }^{3}$ \\ ${ }_{1}^{1}$ Program Studi Magister Teknik Elektro, Universitas Syiah Kuala \\ 2Jurusan Teknik Elektro dan Komputer, Universitas Syiah Kuala \\ ${ }^{3}$ Jurusan Informatika, Universitas Syiah Kuala \\ 1,2,3 Jalan T. Nyak Arief Darussalam, Banda Aceh, Indonesia 23111 \\ e-mail:1njer.purnama@gmail.com, 2nasaruddin@unsyiah.ac.id, 3niz4muddin@unsyiah.ac.id
}

\begin{abstract}
Flooding is the most common natural disaster in Indonesia. Damage caused by floods is a global problem in order to reduce the loss of life and losses economically. Mapping flood-prone areas is one of the solutions to flood disaster mitigation. The method of mapping flood-prone areas generally uses manual mapping so that requires large resources such as mapping, cost and inefficient data updating. In addition, mapping using conventional Geographic Information System is used to automate the mapping with fast and efficient results. Therefore, this study aims to create a geoprocessing model as a new tool in ArcGIS to automatically map flood-prone areas and evaluate the performance of these automation methods. Automation is done by assembling each stage of mapping flood-prone areas conventionally into a tool that runs every stage on one process. Through the application of the geoprocessing model to automate mapping of flood-prone areas, a better performance improvement is obtained than conventional maps of flood-prone areas. Mapping flood-prone areas automatically requires an average of 2 minutes 32 seconds. This automation tool has also been tested using the System Usability Scale method, the results obtained with an average value of 81.66 are included in category $B$ (Excellent).
\end{abstract}

Keywords: Flood; GIS; Mapping; Model builder; Automation.

\begin{abstract}
Abstrak
Banjir merupakan bencana alam yang paling sering terjadi di Indonesia. Kerusakan yang diakibatkan oleh bencana banjir menjadi permasalahan global untuk bisa mengurangi korban jiwa dan kerugian secara ekonomi. Pemetaan daerah rawan banjir merupakan salah satu solusi dalam mitigasi bencana banjir. Metode pemetaan daerah rawan banjir umumnya menggunakan pemetaan secara manual sehingga membutuhkan sumber daya yang besar seperti waktu pemetaan, biaya dan tidak efisien dalam pemutakhiran data. Selain itu, pemetaan dengan menggunakan Geographic Information System secara konvensional digunakan secara otomatisasi pemetaannya dengan hasil cepat dan efisien. Oleh karena itu, penelitian ini bertujuan membuat model geoprocessing sebagai tool baru pada ArcGIS untuk pemetaan daerah rawan banjir secara otomatis dan mengevaluasi kinerja metode otomatisasi tersebut. Otomatisasi dilakukan dengan merangkai setiap tahapan pemetaan daerah rawan banjir secara konvensional menjadi sebuah tool yang menjalankan setiap tahapan hanya dalam sekali proses. Melalui penerapan model geoprocessing untuk otomatisasi pemetaan daerah rawan banjir maka didapatkan peningkatan kinerja yang lebih baik dibandingkan pembuatan peta daerah rawan banjir secara konvensional. Pemetaan daerah rawan banjir secara otomatis membutuhkan waktu rata-rata 2 menit 32 detik. Tool otomatisasi ini juga telah diuji menggunakan metode System Usability Scale dimana hasil yang didapatkan dengan nilai rata-rata 81,66 yang termasuk ke dalam kategori B (Excellent).
\end{abstract}

Kata Kunci: Banjir; GIS; Pemetaan; Model builder; Otomatisasi.

\section{Pendahuluan}

Banjir merupakan bencana alam yang besar terutama di bidang sosial dan ekonomi, cuaca ekstrim yang sering terjadi di seluruh dunia menyebabkan frekuensi banjir terus meningkat dan terjadi kerusakan yang semakin luas pada suatu daerah [1]. Pemetaan daerah rawan banjir merupakan salah satu solusi dalam mitigasi bencana banjir. Bencana banjir dapat dikelola secara

Model Geoprocessing untuk Otomatisasi Pemetaan Daerah Rawan Banjir Berbasis GIS

(N.Purnama) 
efisien dengan adanya pemetaan yang berisi informasi kerentanan daerah, bahaya dan dampak bencana banjir. Keakuratan informasi sangat dipengaruhi dengan data terbaru yang sesuai dengan kondisi yang terjadi pada saat itu juga. Selain itu, metode yang digunakan untuk menentukan daerah yang berpotensi banjir harus akurat [2].Bencana banjir bisa diidentifikasi menggunakan informasi berbasis Geographic Information System (GIS) dan Remote Sensing (RS).

Teknik GIS dan RS dapat digunakan untuk membuat pemodelan bencana banjir [3]. GIS menjalankan prosedur otomatis untuk menghasilkan sistem model distribusi berorientasi objek dari berbagai utilitas database. Otomatisasi dalam proses pembuatan peta dapat menghindari kesalahan dan mengurangi alur kerja atau tahapan yang lebih banyak dalam proses pembuatannya [4]. Sesuai dengan peraturan Kepala Badan Nasional Penanggulangan Bencana (BNPB) Nomor 2 Tahun 2012, maka metode pemetaan resiko bencana terdiri dari tiga bagian peta, yaitu peta ancaman, peta kerentanan dan peta kapasitas [5].

Sedangkan pemetaan daerah rawan banjir pada penelitian ini merupakan salah satu jenis peta ancaman [6].Pemetaan daerah rawan banjir saat ini dibuat menggunakan data dengan periode waktu tertentu sehingga data yang digunakan bukan data yang diperbaharui secara real time dan berkelanjutan. Pembuatan peta membutuhkan waktu yang lama karena menjalankan setiap tahapan secara berurutan untuk melakukan proses spasial analisis data curah hujan dan data spasial pendukung yaitu data ketinggian, data bentuk lereng, data penggunaan lahan dan data zona banjir [7]. Dengan metode otomatisasi pada pembuatan peta, maka pemetaan daerah rawan banjir dapat dibuat dengan mudah dan cepat menggunakan tool yang akan memproses setiap tahapan dengan masukan data secara real time.

Penelitian ini merancang model geoprocessing sebagai sebuah tool pemetaan daerah rawan banjir secara otomatis berbasis GIS. Otomatisasi dilakukan dengan memproses setiap tahapan pembuatan peta daerah rawan banjir dengan menjalankan too/tersebut. Data curah hujan merupakan data yang dapat dimasukan secara update sedangkan data spasial pendukung diproses secara otomatis sehingga informasi dapat dihasilkan dengan cepat dan lebih efektif. Selain itu, penelitian ini juga menghasilkan model geoprocessing pemetaan daerah rawan banjir secara otomatis yang menjadi metode dalam melakukan otomatisasi pemetaan daerah rawan banjir. Otomatisasi pemetaan daerah rawan banjir menghasilkan informasi peta daerah rawan banjir sesuai dengan wilayah administrasi yang dibutuhkan, baik untuk tingkat provinsi, tingkat kabupaten dan pada tingkat kecamatan. Sehingga model geoprocessing atau tool baru ini dapat menyajikan informasi pemetaan daerah rawan banjir dengan mudah, cepat dan akurat sehingga menjadi bahan pertimbangan dalam mengambil keputusan untuk mengurangi dampak dan resiko dari bencana banjir.

\section{Metode Penelitian}

Penelitian ini merangkum setiap tahapan pembuatan peta rawan banjir secara konvensional menjadi sebuah model geoprocessing yang bisa menjalankan setiap tahapan hanya dalam sekali proses. Otomatisasi dalam pembuatan peta daerah rawan banjir dilakukan dengan membuat too/ pemetaan daerah rawan banjir pada ArcGIS. Tool ini dirancang dengan melakukan masukan data yang dilakukan oleh pengguna, data yang dimasukan adalah data curah hujan dan data spasial yang terdiri dari data ketinggian, data kemiringan (Slope), data penggunaan lahan dan data zona banjir. Kemudian data tersebut di proses pada perangkat lunak ArcGis dengan menggunakan tool pemetaan daerah rawan banjir yang menjalankan setiap tahapan geoprocessing secara otomatis. Proses tersebut menghasilkan keluaran berupa shapefile peta daerah rawan banjir, seperti yang terlihat pada Gambar 1.

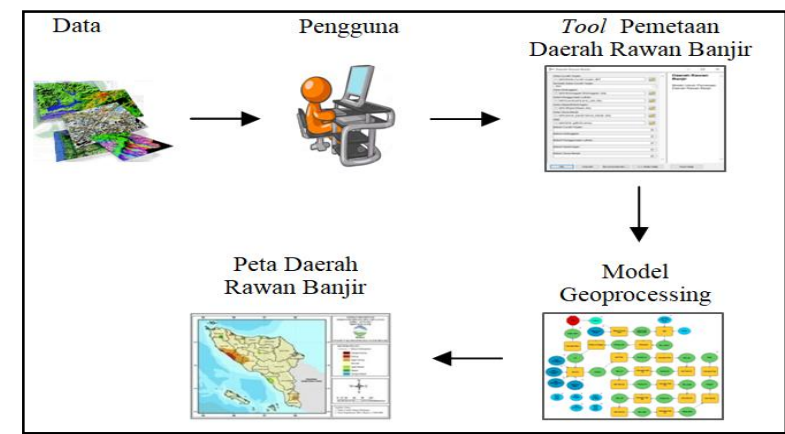

Gambar 1. Konsep otomatisasi pemetaan daerah rawan banjir 
Gambar 1 menunjukkan ilustrasi konsep otomatisasi pemetaan daerah rawan banjir berbasis GIS. Pengguna atau user melakukan masukan Data curah hujan dan data spasial yaitu data ketinggian, data kemiringan (Slope), data penggunaan lahan dan data zona banjir dengan menggunakan too/ pemetaan daerah rawan banjir. Kemudian pengguna menentukan besaran nilai bobot untuk masing-masing parameter data.

Tool pemetaan daerah rawan banjir akan memproses setiap tahapan geoprocessing secara otomatis yang akan menghasilkan keluaran shapefile peta daerah rawan banjir. Dengan demikian, metode penelitian yang digunakan adalah melalui tiga tahapan berikut:

\section{- Perancangan Model Builder}

Semua tool pemetaan daerah rawan banjir dirancang dan dibuat menggunakan model builder yang merupakan aplikasi yang mempunyai fasilitas untuk membuat tool atau model. Model builder merupakan komponen pada software ArcGIS untuk merancang model, membuat simulasi dan melakukan analisis yang bersifat grafis [8]. Model builder memudahkan untuk bisa memahami alur tahapan dari sebuah model karena direpresentasikan kedalam bentuk flow chart dari setiap proses yang dijalankan dan digunakan untuk membuat tool yang bersahabat dan mudah digunakan oleh pengguna [9].

\section{- Penentuan Kriteria dan Pembobotan}

Data yang digunakan untuk pemetaan daerah rawan banjir memiliki kriteria yang berbedabeda antara satu penelitian dengan penelitian lainnya. Pada penelitian ini, data curah hujan, data ketinggian, data penggunaan lahan dan data bentuk lereng dibagi kedalam lima kriteria [7]. Sedangkan data zona banjir dibagi menjadi dua kriteria, data ini berbentuk data spasial (shapefile) yang diperoleh dari Kementrian Pekerjaan Umum dan Perumahan Rakyat (PUPR). Setelah setiap data memiliki kriteria, maka dilakukan skoring data untuk menentukan besaran nilai skor pada masing-masing kriteria data. Data curah hujan, data ketinggian, data penggunaan lahan dan data bentuk lereng skor paling kecil bernilai 1 dan skor paling besar bernilai 5 . Sedangkan data zona banjir merupakan data histori wilayah yang sudah pernah terjadi banjir, data zona banjir dibagi menjadi dua kriteria, untuk wilayah yang sudah pernah terjadi banjir diberi nilai skor 2 sedangkan wilayah yang belum pernah terjadi banjir diberi nilai skor 0 . Kriteria yang memiliki pengaruh paling kuat dalam penentuan pemetaan daerah rawan banjir, maka nilai skor untuk kriteria tersebut semakin besar. Selain dari penentuan kriteria dan skoring data, pembobotan juga dilakukan pada masing-masing data. Data yang memiliki pengaruh paling besar dalam penentuan daerah rawan banjir akan diberikan nilai bobot yang paling tinggi. Pada penelitian ini, pemberian nilai bobot bersifat dinamis, sehingga nilai bobot pada tool pemetaan daerah rawan banjir bisa diubah atau ditentukan pengguna sesuai dengan kebutuhan atau referensi yang dimiliki.

\section{- Evaluasi Kinerja}

Evaluasi kinerja otomatisasi pemetaan daerah rawan banjir dilakukan dengan membandingkan antara pemetaan daerah rawan banjir secara konvensional dengan pemetaan daerah rawan banjir menggunakan tool. Parameter yang digunakan yaitu tahapan dan waktu yang dibutuhkan dalam pemetaan daerah rawan banjir. Informasi waktu yang dibutuhkan dalam melakukan pemetaan daerah rawan banjir metode konvensional diperoleh dengan cara mengedarkan kuesioner. Sedangkan untuk informasi waktu yang dibutuhkan untuk melakukan pemetaan daerah rawan banjir metode otomatis dilakukan dengan uji langsung too/ pemetaan daerah rawan banjir. Selain itu juga dilakukan evaluasi uji kegunaan tool pemetaan daerah rawan banjir menggunakan metode System Usability Scale (SUS). Tingkat kepuasan pengguna dalam menggunakan suatu produk dapat diukur dengan kuesioner SUS. Skor atau skala pada SUS dihitung dengan aturan yang sudah ditentukan dengan 10 jenis pertanyaan. Skor SUS diperoleh dengan aturan yaitu apabila pertanyaan dengan nomor ganjil maka nilai skor yang dipilih dikurangi dengan nilai 1, sedangkan pertanyaan dengan nomor genap maka nilai 5 dikurangi dengan nilai skor yang dipilih. Setelah skor dari masing-masing pertanyaan dijumlahkan, maka jumlah skor dikalikan dengan nilai 2,5 untuk mengkonversi nilai kemungkinan yang akan muncul dari 0 sampai dengan 100 [10]. Berdasarkan Pengujian menggunakan metode SUS, akan diperoleh nilai indeks yang menunjukkan apakah tool pemetaan daerah rawan banjir memiliki kualitas yang baik dan mudah untuk digunakan. 


\subsection{Rancangan Tool Daerah Rawan Banjir}

Tool daerah rawan banjir dirancang menggunakan model builder yang terdapat pada perangkat lunak ArcGis. Setiap tahapan yang dirancang yaitu proses masukan data, proses spasial analisis, penentuan model parameter yang ditampilkan untuk menjadi menu pada tool sampai dengan penentuan keluaran semua dimasukkan kedalam jendela model builder. Rancangan tool daerah rawan banjir diperlihatkan pada Gambar 2.

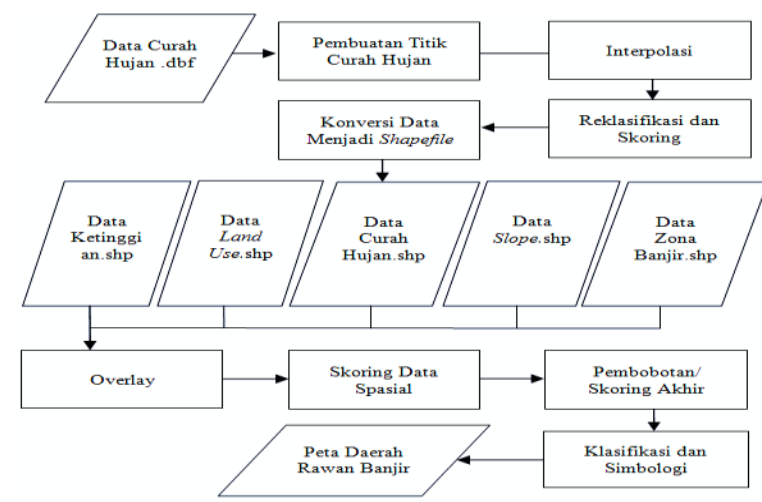

Gambar 2 Alur rancangan Tool pemetaan daerah rawan banjir

Gambar 2 menunjukkan Tahapan yang dilakukan dalam perancangan tool pemetaan daerah rawan banjir yaitu masukan data curah hujan dan interpolasi data curah hujan, interpolasi curah hujan menggunakan metode Inverse distance Wieghted (IDW). Metode ini berfungsi memberi nilai curah hujan pada bagian yang tidak memiliki stasiun pengamatan curah hujan, nilai data curah hujan diambil atau dikombinasikan dari titik-titik pengamatan curah hujan yang terdekat [11]. Setelah itu dilakukan proses reklasifikasi dan skoring data curah hujan, overlay data curah hujan dan data spasial, skoring data spasial, pembobotan/skoring akhir, kemudian klasifikasi dan simbologi.Tahapan-tahapan pembuatan tool pemetaan daerah rawan banjir yaitu membuat file geodatabase pada perangkat lunak ArcGIS. Kemudian menambahkan data curah hujan, data ketinggian, data penggunaan lahan, data bentuk lereng dan data zona banjir ke dalam model builder pada perangkat lunak ArcGIS. Melakukan proses interpolasi data curah hujan. Melakukan reklasifikasi dan skoring data dari hasil interpolasi curah hujan. Melakukan konversi data curah hujan dari format raster menjadi vektor/shapefile. Melakukan proses overlay semua data yaitu data curah hujan, data ketinggian, data penggunaan lahan, data bentuk lereng dan data zona banjir. Melakukan skoring data pada masing-masing data spasial. Melakukan akumulasi nilai skor dari semua data yang digunakan. Melakukan pembobotan/skoring akhir. Melakukan proses klasifikasi dan simbologi. Menentukan model parameter yang menjadi menu masukan pada tool pemetaan daerah rawan banjir.

\subsection{Kriteria dan Pembobotan Data}

Setiap data yang digunakan pada pemetaan daerah rawan banjir yaitu data curah hujan, data ketinggian, data penggunaan lahan dan data bentuk lereng memiliki kriteria dan nilai skoring yang telah ditentukan [7], sedangkan data zona banjir diperoleh dari Kementrian Pekerjaan Umum dan Perumahan Rakyat (PUPR). Pembobotan data bersifat dinamis yang dapat ditentukan oleh pengguna sesuai dengan kebutuhan atau referensi yang dimiliki, pada penelitian ini nilai bobot setiap kriteria diberikan sama besar dengan nilai 20. Kriteria dan Pembobotan data ditunjukkan pada Tabel 1.

Tabel 1. Kriteria dan pembobotan data

\begin{tabular}{ccccc}
\hline No & Data & \multicolumn{1}{c}{ Kriteria } & Skoring & Bobot (\%) \\
\hline \multirow{2}{*}{1} & Curah Hujan & Curah Hujan $<50 \mathrm{~mm}$ & 1 & 20 \\
\cline { 3 - 4 } & $(\mathrm{CH})$ & Curah Hujan $50-100 \mathrm{~mm}$ & 2 & \\
\cline { 3 - 4 } & & Curah Hujan $100-200 \mathrm{~mm}$ & 3 & \\
& & &
\end{tabular}

Model Geoprocessing untuk Otomatisasi Pemetaan Daerah Rawan Banjir Berbasis GIS

(N.Purnama) 
Jurnal IImu Teknik Elektro Komputer dan Informatika (JITEKI)

Vol. 4, No.2, Desember 2018

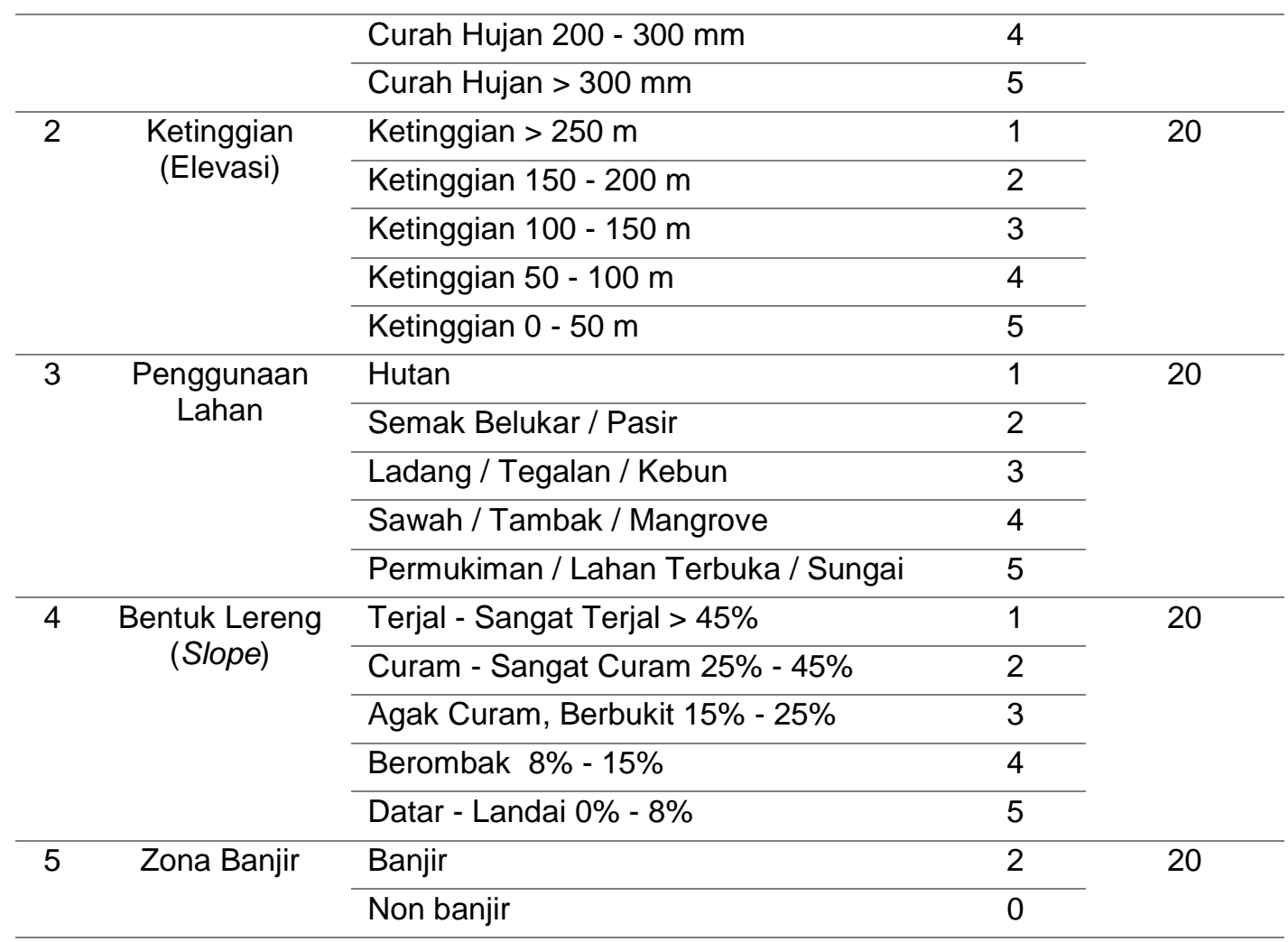

Tabel 1 menunjukkan data curah hujan dengan kriteria curah hujan lebih kecil dari $50 \mathrm{~mm}$ memiliki nilai skor 1, curah hujan dengan kriteria tersebut mempunyai pengaruh yang kecil untuk peluang terjadi banjir. Sedangkan jumlah curah hujan yang tinggi dengan kriteria curah hujan lebih besar dari $300 \mathrm{~mm}$ diberi nilai skor 5 , sehingga semakin tinggi jumlah curah hujan maka nilai skor semakin besar dan berpotensi untuk terjadi banjir pada suatu wilayah. Data ketinggian dengan kriteria ketinggian lebih besar dari 250 meter di atas permukaan laut diberi nilai skor 1, karena semakin tinggi suatu wilayah diasumsikan potensi terjadi banjir semakin berkurang, sehingga semakin tinggi suatu wilayah maka nilai skor semakin kecil. Sedangkan ketinggian dengan kriteria 0 sampai dengan 50 meter di atas permukaan laut diberi nilai skor 5 , sehingga untuk wilayah dataran rendah lebih berpotensi untuk terjadi banjir. Data penggunaan lahan dengan kriteria kawasan hutan diberi nilai skor 1, karena serapan air pada kawasan hutan dianggap baik, jadi semakin baik resapan air pada suatu daerah maka potensi terjadi banjir semakin kecil, sehingga semakin baik resapan air pada kriteria data penggunaan lahan maka nilai skor semakin kecil. Sedangkan kawasan dengan kriteria permukiman / lahan terbuka / sungai memiliki nilai skor paling tinggi yang mempunyai potensi yang lebih besar terjadi banjir. Data bentuk lereng dengan kriteria terjal sampai sangat terjal dengan kemiringan lebih dari $45 \%$ diberi nilai skor 1 , karena semakin tinggi kemiringan suatu wilayah maka akan mengurangi adanya genangan air, sehingga untuk wilayah yang terjal maka nilai skor semakin kecil. Sedangkan semakin datar atau landai suatu wilayah maka potensi terjadi genangan air semakin besar pada wilayah tersebut yang diberi skor 5 untuk kriteria bentuk lereng datar hingga landai. Data zona banjir dengan kriteria banjir diberi nilai skor 2, karena pada wilayah tersebut sudah pernah terjadi banjir. Sedangkan zona banjir dengan kriteria non banjir diberi nilai skor 0 , hal ini disebabkan karena pada wilayah tersebut belum pernah terjadi banjir sehingga memiliki potensi banjir yang lebih kecil dibandingkan wilayah yang sudah pernah terjadi banjir. Data yang memiliki pengaruh paling besar maka diberikan nilai bobot yang paling tinggi. Pada penelitian ini, setiap parameter data dianggap memiliki pengaruh yang sama besar, sehingga nilai bobot masing-masing data diberi nilai bobot 20. Berdasarkan kriteria dan pembobotan data yang terdapat pada tabel 1 maka diperoleh nilai skor total minimum yaitu 4 dan skor total maksimum yaitu 22, skor tersebut berasal dari penjumlahan skor minimum dan juga skor maksimum dari kriteria dan pembobotan data curah hujan, data ketinggian, data penggunaan lahan, data bentuk lereng dan data zona banjir. Berdasarkan nilai skor minimum dengan skor maksimum maka terdapat range skor dengan nilai 19. Nilai range tersebut dibagi untuk 3 kategori, 
sehingga setiap kategori mempunyai nilai range sekitar 6 skor seperti yang diperlihatkan pada Tabel 2 .

Tabel 2. Kategori daerah rawan banjir

\begin{tabular}{lcc}
\hline No & Skor Total & Tingkat Kerawanan Banjir \\
\hline 1 & Nilai Skor $<11$ & Rendah \\
\hline 2 & $11 \leq$ Nilai Skor $\leq 16$ & Menengah \\
\hline 3 & Nilai Skor $>16$ & Tinggi \\
\hline
\end{tabular}

Pada Tabel 2 terlihat, berdasarkan nilai skor total maka kategori rawan banjir di klasifikasikan menjadi tiga tingkat kerawanan banjir, yaitu tingkat kerawanan rendah, menengah dan tinggi [12]. Tingkat kerawanan rendah dengan nilai skor lebih kecil dari 11. Tingkat kerawanan menengah dengan nilai skor antara 11 sampai dengan nilai skor 16 dan tingkat kerawanan tinggi dengan nilai skor lebih besar dari 16 . Setelah mempunyai kategori tingkat kerawanan pemetaan daerah rawan banjir, maka dilakukan proses simbologi dengan memberikan warna pada setiap kategori. Warna hijau untuk simbol kategori rendah, warna kuning untuk simbol kategori menengah dan warna merah untuk simbol kategori tinggi [12].

\section{Hasil dan Pembahasan}

\subsection{Model Geoprocessing}

Tool pemetaan daerah rawan banjir menjalankan proses dari setiap tahapan yang dimulai dengan melakukan masukan data curah hujan, data ketinggian, data penggunaan lahan, data bentuk lereng dan data zona banjir yang akan menghasilkan keluaran peta daerah rawan banjir. Metode otomatisasi pemetaan daerah rawan banjir ditunjukkan pada Gambar 3.

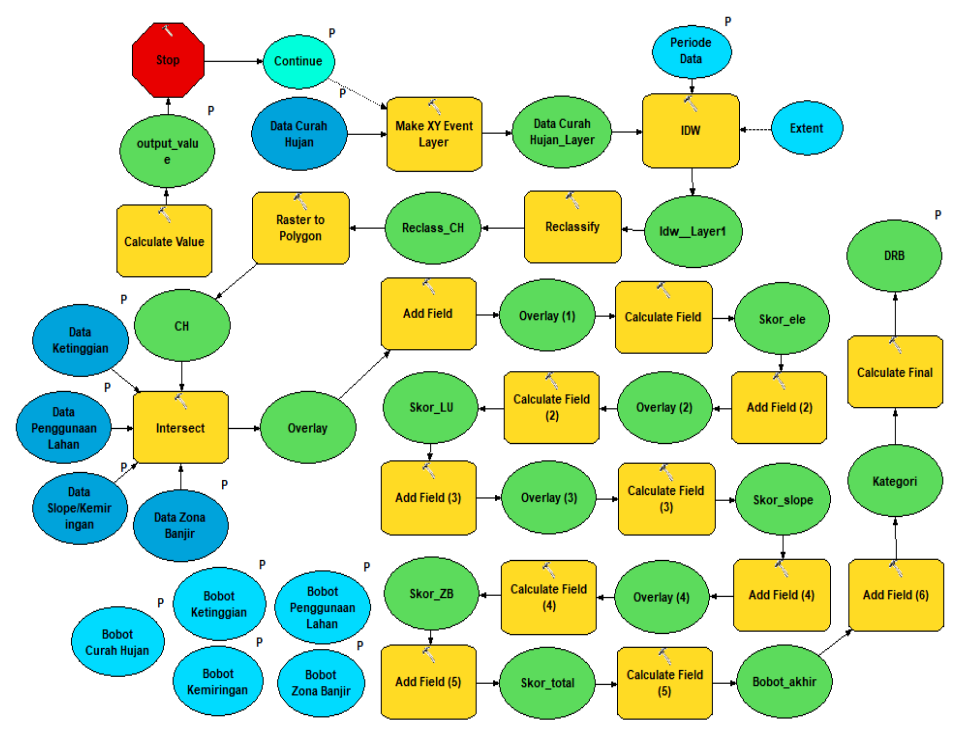

Gambar 3. Model geoprocessing otomatisasi pemetaan daerah rawan banjir

Pada Gambar 3 terlihat setiap masukan data dijadikan sebagai model parameter yang dilambangkan dengan simbol huruf $\mathrm{P}$. Model parameter bertujuan untuk menampilkan menu pada tool pemetaan daerah rawan banjir sesuai dengan yang dibutuhkan. Model parameter berikutnya yaitu variabel periode data curah hujan dari toolbox IDW, keluaran atau hasil peta daerah rawan banjir serta bobot dari setiap data yang digunakan. Nilai pembobotan pada tool pemetaan daerah rawan banjir bersifat dinamis, pengguna bisa menentukan nilai bobot masingmasing data sesuai dengan referensi yang dimiliki.

Otomatisasi pemetaan daerah rawan banjir berbasis GIS menghasilkan sebuah tool pemetaan daerah rawan banjir yang bisa menjalankan setiap tahapan pembuatan peta daerah rawan banjir secara konvensional hanya dalam sekali proses. Tool pemetaan daerah rawan banjir menghasilkan shapefile (shp) peta daerah rawan banjir. 
Jurnal IImu Teknik Elektro Komputer dan Informatika (JITEKI)

Vol. 4, No.2, Desember 2018

\subsection{Tool Pemetaan Daerah Rawan Banjir}

Tool pemetaan daerah rawan banjir dapat dimasukkan ke dalam default Toolbox pada perangkat lunak ArcGIS, sehingga toolbox Daerah Rawan Banjir bisa dipilih melauli menu ArcToolbox. Tampilan menu tool pemetaan daerah rawan banjir seperti yang diperlihatkan pada Gambar 4.

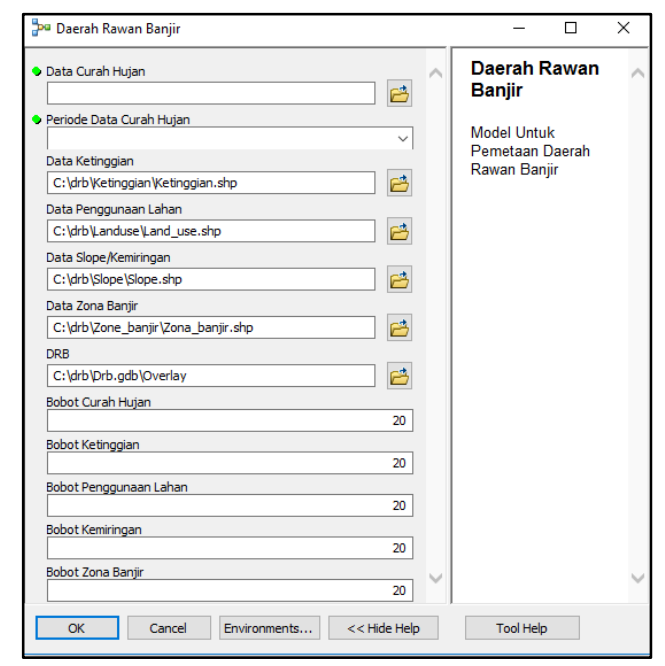

Gambar 4. Menu Tool pemetaan daerah rawan banjir

Dari Gambar 4 terlihat tampilan menu Too/Daerah Rawan Banjir, Pada bagian kolom Data Curah Hujan merupakan bagian untuk memasukkan file data curah hujan, periode data curah hujan yang akan digunakan terdapat pada kolom Periode Data Curah Hujan. Selanjutnya data ketinggian dimasukkan pada kolom Data Ketinggian, data penggunaan lahan dimasukkan pada kolom Data Penggunaan Lahan, data bentuk lereng dimasukkan pada kolom data Data Slope/Kemiringan, data zona banjir dimasukkan pada kolom Data Zona Banjir. Sedangkan kolom DRB merupakan lokasi penyimpanan shapefile hasil proses dari tool pemetaan daerah rawan banjir. Bobot Data Curah Hujan, Bobot Ketinggian, Bobot Penggunaan Lahan, Bobot Kemiringan dan Bobot Zona Banjir memiliki nilai default 20 dengan anggapan setiap parameter data mempunyai pengaruh yang sama kuat dalam pemetaan daerah rawan banjir, nilai bobot bersifat dinamis sehingga dapat dimasukan sesuai dengan kebutuhan pengguna atau sesuai dengan referensi yang digunakan.

\subsection{Peta Daerah Rawan Banjir}

Setelah menjalankan tool pemetaan daerah rawan banjir maka akan diperoleh shapefile (shp) peta daerah rawan banjir. Peta yang dihasilkan akan menyesuaikan dengan luasan wilayah data spasial yang dimasukan, sehingga bisa menghasilkan peta daerah rawan banjir pada tingkat provinsi, tingkat kabupaten dan tingkat kecamatan sesuai dengan data spasial dan data curah hujan yang dimiliki. Pada penelitian ini menggunakan data spasial Provinsi Aceh dan menggunakan data curah hujan Bulan Januari Tahun 2017 dari beberapa titik pengamatan di Provinsi Aceh. Peta daerah rawan banjir Provinsi Aceh diperlihatkan pada Gambar 5.

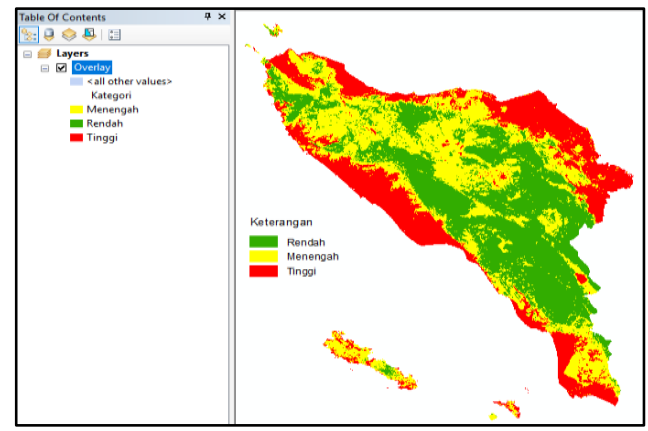

Gambar 5. Shapefile peta daerah rawan banjir provinsi aceh 
Gambar 5 merupakan hasil atau keluaran dari tool pemetaan daerah rawan banjir pada tingkat provinsi yang terdiri dari 3 kategori tingkat kerawanan yaitu kategori Rendah, Menengah dan Tinggi. Peta tersebut memiliki hasil yang sama dengan pemetaan daerah rawan banjir yang dilakukan secara bertahap dengan metode konvensional. Dengan demikian too/ pemetaan daerah rawan banjir sudah menjalankan semua proses geoprocessing dengan benar. Hasil pemetaan daerah rawan banjir metode konvensional terlihat pada gambar 6 .

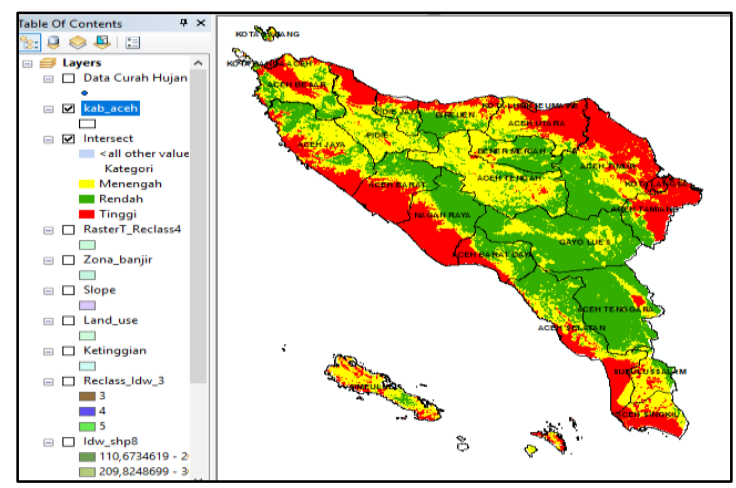

Gambar 6. Shapefile peta daerah rawan banjir provinsi aceh metode konvensional

\subsection{Kinerja Tool Pemetaan Daerah Rawan Banjir}

Otomatisasi pemetaan daerah rawan banjir sangat memudahkan pengguna, dengan menggunakan too/pemetaan daerah rawan banjir, maka waktu yang dibutuhkan dalam melakukan pemetaan daerah rawan banjir juga semakin cepat. Dari hasil kuesioner beberapa pengguna ArcGIS yang pernah melakukan pemetaan daerah rawan banjir dengan menggunakan metode konvensional diperoleh informasi waktu yang digunakan dalam pemetaan daerah rawan banjir. Responden terdiri dari pegawai negeri sipil dan juga beberapa mahasiswa. Pengguna 1 sampai dengan pengguna 10 merupakan responden yang berasal dari staf kantor Stasiun Klimatologi Aceh Besar, sedangkan pengguna 11 sampai dengan pengguna 15 merupakan mahasiswa Jurusan Informatika Fakultas MIPA, Universitas Syiah Kuala. Informasi waktu hasil kuesioner dari responden, dibandingkan dengan waktu yang dibutuhkan untuk pemetaan daerah rawan banjir menggunakan tool (metode otomatis) yang telah dilakukan pengujian sebanyak 15 kali percobaan. Perbandingan waktu pemetaan daerah rawan banjir dapat dilihat pada Tabel 3.

Tabel 3. Perbandingan waktu pemetaan daerah rawan banjir

\begin{tabular}{|c|c|c|}
\hline Pengguna & $\begin{array}{l}\text { Tanpa Menggunakan Tool } \\
\text { (Metode Konvensional) }\end{array}$ & $\begin{array}{c}\text { Menggunakan } \\
\text { Tool Otomatisasi }\end{array}$ \\
\hline Pengguna 1 & Lebih dari 120 menit & 2 menit 31 detik \\
\hline Pengguna 2 & Lebih dari 120 menit & 2 menit 41 detik \\
\hline Pengguna 3 & Lebih dari 120 menit & 2 menit 29 detik \\
\hline Pengguna 4 & Lebih dari 120 menit & 2 menit 31 detik \\
\hline Pengguna 5 & Lebih dari 120 menit & 2 menit 33 detik \\
\hline Pengguna 6 & Lebih dari 120 menit & 2 menit 30 detik \\
\hline Pengguna 7 & $30 \mathrm{~s} / \mathrm{d} 60$ menit & 2 menit 40 detik \\
\hline Pengguna 8 & $60 \mathrm{~s} / \mathrm{d} 90$ menit & 2 menit 35 detik \\
\hline Pengguna 9 & $90 \mathrm{~s} / \mathrm{d} 120$ menit & 2 menit 30 detik \\
\hline Pengguna 10 & $60 \mathrm{~s} / \mathrm{d} 90$ menit & 2 menit 31 detik \\
\hline Pengguna 11 & 60 s/d 90 menit & 2 menit 33 detik \\
\hline Pengguna 12 & Lebih dari 120 menit & 2 menit 32 detik \\
\hline Pengguna 13 & 90 s/d 120 menit & 2 menit 30 detik \\
\hline Pengguna 14 & $90 \mathrm{~s} / \mathrm{d} 120$ menit & 2 menit 30 detik \\
\hline Pengguna 15 & $90 \mathrm{~s} / \mathrm{d} 120$ menit & 2 menit 29 detik \\
\hline
\end{tabular}


Dari Tabel 3 terlihat perbandingan waktu yang dibutuhkan dalam melakukan pemetaan daerah rawan banjir antara metode konvensional dengan metode otomatis. Tanpa menggunakan tool (metode konvensional) waktu minimal yang dibutuhkan yaitu 30 menit, sedangkan dengan menggunakan tool pemetaan daerah rawan banjir (metode otomatisasi) dari hasil percobaan sebanyak 15 kali maka diperoleh waktu rata-rata selama 2 menit 32 detik. Percobaan tersebut menunjukkan untuk menghasilkan peta daerah rawan banjir dengan menggunakan tool (metode otomatisasi) hanya membutuhkan waktu sekitar 2 menit 32 detik.

Selain mengevaluasi kinerja pemetaan daerah rawan banjir secara otomatis, penelitian ini juga melakukan pengujian kegunaan dari tool pemetaan daerah rawan banjir. Tes kegunaan pada tool pemetaan daerah rawan banjir dilakukan melalui kuesioner dengan metode System Usability Scale (SUS) [10]. Dari hasil kuesioner dengan metode SUS, diperoleh data seperti yang terlihat pada Tabel 4.

Tabel 4. Hasil kuesioner sus tool pemetaan daerah rawan banjir

\begin{tabular}{cccc}
\hline Responden & Nilai SUS & Responden & Nilai SUS \\
\hline Pengguna 1 & 75 & Pengguna 9 & 85 \\
\hline Pengguna 2 & 77,5 & Pengguna 10 & 82,5 \\
\hline Pengguna 3 & 85 & Pengguna 11 & 87,5 \\
\hline Pengguna 4 & 85 & Pengguna 12 & 80 \\
\hline Pengguna 5 & 72,5 & Pengguna 13 & 80 \\
\hline Pengguna 6 & 87,5 & Pengguna 14 & 85 \\
\hline Pengguna 7 & 77,5 & Pengguna 15 & 87,5 \\
\hline Pengguna 8 & 77,5 & &
\end{tabular}

Berdasarkan hasil kuesioner dengan metode SUS, diperoleh nilai terendah yaitu 72,5 dan nilai tertinggi yaitu 87,5 dengan nilai rata-rata 81,66 . Berdasarkan nilai tersebut maka tool pemetaan daerah rawan banjir memperoleh indeks B (Excellent). Hasil ini menunjukkan bahwa tool pemetaan daerah rawan banjir mempunyai kualitas yang baik dan mudah digunakan [10].

\section{Kesimpulan}

Tool pemetaan daerah rawan banjir dapat digunakan secara umum untuk wilayah administrasi yang berbeda-beda, baik pada tingkat provinsi, tingkat kabupaten dan juga pada tingkat kecamatan. Pemetaan daerah rawan banjir metode otomatis dengan menggunakan tool mempunyai kinerja yang lebih baik dibandingkan metode konvensional. Pemetaan daerah rawan banjir metode konvensional membutuhkan waktu antara 30 menit sampai dengan lebih dari 120 menit, sedangkan metode otomatis hanya membutuhkan antara 2 menit 29 detik sampai dengan 2 menit 41 detik. Selisih waktu antara metode konvensional dengan metode otomatis paling sedikit yaitu 27 menit 31 detik. Pemetaan daerah rawan banjir menggunakan tool membutuhkan waktu rata-rata 2 menit 32 detik. Tool pemetaan daerah rawan banjir mempunyai kualitas sangat baik dan mudah digunakan yang sudah diuji dengan menggunakan metode System Usability Scale (SUS). Hasil SUS memperoleh nilai rata-rata 81,66 yang masuk ke dalam grade B (Excellent).

\section{Referensi}

[1] Pulvirenti L, Pierdicca N, Boni G, Fiorini M, Rudari R. "Flood Damage Assessment Through Multitemporal COSMO-SkyMed Data and Hydrodynamic Models: The Albania 2010 Case Study". IEEE Journal of Selected Topics in Applied Earth Observations and Remote Sensing.; vol. 7, no. 7, pp. 2848-2855, 2014.

[2] Pradhan B, Tehrany MS, Jebur MN. "A New Semiautomated Detection Mapping of Flood Extent From TerraSAR-X Satellite Image Using Rule-Based Classification and Taguchi Optimization Techniques". IEEE Transactions on Geoscience and Remote Sensing, vol.54, no.7, pp. 4331-4342, 2016. 
[3] Tehrany MS, Pradhan B, Jebur MN. "Spatial Prediction of Flood Susceptible Areas Using Rule Based Decision Tree (DT) and A Novel Ensemble Bivariate and Multivariate Statistical Models in GIS". Journal of Hydrology, vol.504, pp. 69-79, 2013.

[4] Darmawan K, Hani'ah, Suprayogi A. "Analisis Tingkat Kerawanan Banjir Di Kabupaten Sampang Menggunakan Metode Overlay Dengan Scoring Berbasis Sistem Informasi Geografis". Jurnal Geodesi Undip, vol.6, hal. 31-40, 2017.

[5] Nasaruddin, Ardiansyah, Munadi K. "Interactive Internet-based Disaster Risk Information System for Tsunami-hit Aceh Province of Indonesia". Journal of Information and Communication Technology (JICT), vol. 15, no.1, pp. 33-55, 2016.

[6] Nasaruddin, Munadi K, Dirhamsyah M, Yuliansyah D. "A web-based geographic information system for aceh natural hazards". Telkomnika. Vol.9, no.1, pp. 89-98, 2011.

[7] Haryani NS, Zubaidah A, Dirgahayu D, Yulianto HF, Pasaribu J. "Model Bahaya Banjir Menggunakan Data Penginderaan Jauh Di Kabupaten Sampang (Flood Hazard Model Using Remote Sensing Data in Sampang District)". Jurnal Penginderaan Jauh, vol.9., no.1, hal. 5266, 2012.

[8] ArcGis For Dekstop [Internet]. "Dekstop.arcgis.com". 2017 [cited 21 October 2017].

[9] Dobesova Z. "Strengths and Weaknesses in Data Flow Diagrams in GIS". International Conference on Computer Sciences and Applications. Wuhan, pp. 803-807, 2013.

[10] Brooke J. SUS. "A Retrospective", Journal of Usability Studies, vol.8, no. 2, pp. 29-40, 2013.

[11] Setianto A, Trindiani T. "Comparison Of Kriging and Inverse Distance Weighted (IDW) Interpolation Methods In Lineament Extraction and Analysis". J. SE Asian Appl. Geol, vol.5, no.1, pp. 21-29, 2013.

[12] BNPB. "Peraturan Kepala Badan Nasional Penanggulangan Bencana Nomor 2 Tahun 2012 Tentang Pedoman Umum Pengkajian Risiko Bencana".hal. 15-19, 2012. 